\title{
The Potency of Oral Administration of L-Citrulline as Anti Heat Stress Agent in KUB Chicks
}

\author{
Edi Erwan $^{1^{*}}$, Triani Adelina ${ }^{1}$, Alaiddin Koto ${ }^{2}$ and Vebera Maslami ${ }^{1}$ \\ ${ }^{I}$ Department of Animal Science, Faculty of Agriculture and Animal Science, State Islamic University of Sultan Syarif Kasim Riau, 28293, Indonesia \\ ${ }^{2}$ Faculty of Syariah and Law, State Islamic University of Sultan Syarif Kasim Riau, 28293, Indonesia \\ *Corresponding author's E-mail: erwan_edi@yahoo.com; ORCID: 0000-0002-5306-1582
}

Received: 28 Dec. 2019

Accepted: 04 Feb. 2020

\begin{abstract}
L-citrulline (L-Cit) is considered one of the potential amino acids that are able to reduce body temperature in layer chicks. However, there are no reports on functions of L-Cit in KUB chicks. Therefore, the present study aimed to evaluate the effects of oral administration of L-Cit on feed intake, body temperature and plasma biochemical parameters of KUB chicks over two hours post-administration. Neonatal KUB chicks were orally administered with different doses of L-Cit $(0,3.75,7.5$ and $15 \mathrm{mmol} / \mathrm{kg}$ body weight). At 30, 60 and $120 \mathrm{~min}$, feed intake was determined, also rectal temperature of chicks was measured by using a digital thermometer. At 120 min after administration, the blood samples were immediately collected through the jugular vein, then biochemical parameters of plasma (total cholesterol, triacylglycerol and total glucose) were analyzed. The obtained results indicated that feed intake, body temperature, and plasma metabolites were not significantly influenced by different doses of L-Cit. In conclusion, L-Cit could not able to improve feed intake, decrease body temperature and change plasma metabolites in KUB chicks.
\end{abstract}

Keywords: Body temperature, Feed intake, KUB chick, L- citrulline, Plasma metabolites

\section{INTRODUCTION}

In general, native chickens play an important role in supporting income generation, especially in many underdeveloped countries (Padhi, 2016). KUB chickens are offspring of local chickens in several areas of West Java that are obtained after six generations of a systematically-controlled breeding system (Purbarani et al., 2019). The KUB chickens have several advantages compared to their previous generations as well as local chickens. For instance, KUB chickens have high rates of egg production (160-180 eggs/year), high hatchability, and low feed conversion ratio (Sartika, 2016). Besides that, KUB chicken is considered a meat type breed (Hidayah et al., 2019) and the high demand for chicken meat might potentially be fulfilled by increasing the productivity of KUB chicken.

In order to obtain good performance as an expression of the genetically improved breed, some efforts such as optimal management conditions (housing and feeding), is needed to increase biological and economic productivity. Many factors may influence poultry production in tropical and subtropical areas. The climatic environment is one of the important factors affect production efficiency in these regions (Renaudeau et al., 2012). Poultry experiences heat distress when the combination of relative humidity and ambient temperature rise above the comfort zone (Teeter and Belay, 1996). There are concerns about reduced poultry production due to high ambient temperatures not only in tropical regions but also in some countries that occupy the temperate where heat stress is an occasional problem during the summer months.

Several nutritional strategies have been reported to overcome the adverse effects of heat stress in poultry (Teeter and Belay, 1996; Yahav, 2000; Erwan et al., 2013a, 2014, 2017; Chowdhury et al., 2015). Heat stress reduces laying percentage, egg size, eggshell durability, and body weight gain, as well as increases mortality in layers (Sterling et al., 2003; Lin et al., 2004; FrancoJimenez and Beck, 2007). Also, it appears to have a detrimental impact on poultry meat quality, however, it has been reported that breast meat characteristics remain unaffected by heat stress (Goo et al., 2019).

Nutrients, especially amino acids, are widely used as anti-stress agents with regard to psychological and physiological stress (Yamane et al., 2009; Hamasu et al., 2010; Erwan et al., 2012). Amino acid supplements, 
particularly essential amino acids, has been used in attempts to overcome problems of heat stress in birds (Mendes et al., 1997; Daghir et al., 2003).

It has been reported that oral administration of Lcitrulline (L-Cit) decreased the body temperature in layer chicks (Chowdhury et al., 2015). However, there are no reports on the function of L-Cit in KUB chicks. Therefore, the purpose of this study was to examine the effect of orally administered L- Cit on rectal temperature and some plasma biochemical parameters in KUB chicks.

\section{MATERIALS AND METHODS}

This research was conducted at the Poultry Division Field Laboratory, Faculty of Agriculture and Animal Science, State Islamic University of Sultan Syarif Kasim Riau, Indonesia in 2018.

\section{Ethical approval}

This experiment was carried out in strict accordance with the recommendations in the Guide for the Care and Use of Animal, at the Faculty of Agriculture and Animal Science, State Islamic University of Sultan Syarif Kasim Riau, Pekanbaru, Indonesia

\section{Animals}

Thirty-two, one-day-old, KUB chicks were purchased from a local hatchery and housed in a wiremeshed cage $(50 \times 35 \times 31 \mathrm{~cm})$ at a constant temperature of $30 \pm 1{ }^{\circ} \mathrm{C}$ and with continuous light. Feed (Charoen Phokpand, Indonesia) and water were provided ad libitum. Feed composition is presented in table 1. One day before the experiment, chicks (4 days old) were weighed individually and assigned to treatment and control groups based on their body weight to produce uniform groups. The number of animals used in each group was kept to the minimum $(\mathrm{n}=8)$ that would still ensure adequate statistical power.

Table 1. The percentage of nutrient content in ration

\begin{tabular}{lc}
\hline Nutrient & Value \\
\hline Crude Protein (\%) & 23.50 \\
Crude Fiber (\%) & 1.88 \\
Crude Fat (\%) & 5.87 \\
Ca (\%) & 0.29 \\
P (\%) & 0.15 \\
ME (Kcal/kg) & 3,050 \\
\hline Ca: Calcium, P: Phosphor, ME: Metabolizable Energy; *Commercial \\
feed: 311-VIVO, PT, Charoen Pokphand, Indonesia; **Mineral Premix: \\
Supplemented for kg of the diets: Vit. A, 12000 IU; D3, 2000 IU; E, 20 \\
mg; K3, 3 mg; B2, 7 mg; B3, 12 mg; B5, 3 mg; B12, 0.03 mg; biotin, 0.1 \\
mg; choline chloride, 300 mg; Mn, 130 mg; Fe, 70 mg; Zn, 60 mg; Cu,12 \\
mg; I,1 mg; Se, 0.2 mg, and adequate antioxidant.
\end{tabular}

\section{Experimental design}

After a habituation period, chicks were randomly selected and divided into four groups each consisting of eight chicks. The chicks were reared individually in experimental cages and had ad libitum access to diet up to the time of the experiment. On the day of the experiment, each chick (5 days old) received L-Cit orally (treatment groups) or distilled water (control group) by the plastic needle on small syringe. Based on our recent report on Lor D-Asp and L-Cit in layer chicks (Erwan et al., 2013b, 2014; Chowdhury et al., 2015), treatment groups received $3.75,7.5$ or $15.0 \mathrm{mmol} / \mathrm{kg}$ body weight as the low, medium and high dose, respectively. The chicks were fed ad libitum diets for $2 \mathrm{~h}$ immediately after the treatment. At the end of the experiments $(2 \mathrm{~h}$ after L-Cit administration), birds were decapitated under chloroform anesthesia. Blood samples were collected in heparinized tubes and centrifuged for $15 \mathrm{~min}$ at $5,000 \mathrm{~g}$, and the plasma was collected and stored at $-20{ }^{\circ} \mathrm{C}$ until analysis took place.

\section{Analysis of plasma biochemical parameters}

The biochemical parameters of plasma including total glucose, total cholesterol, and triacylglycerol were determined with Microlab 300 (Vital Scientific, Netherland) as per the manufacturer's instructions. All the samples were assayed together and in a random sequence for each metabolite.

\section{Measurement of feed intake and rectal temperature}

At 30,60 and $120 \mathrm{~min}$ after L-Cit administration, feed intake was calculated by measuring the reduction in the amount of feed consumed from a pre-weighed feeder. Similarly, rectal temperature of chicks was determined at 30, 60 and $120 \mathrm{~min}$ after L-Cit administration using a digital thermometer with an accuracy of $\pm 0.1^{\circ} \mathrm{C}$ (Thermalert TH-5, Physitemp Instruments Inc., USA). It took about $5 \mathrm{sec}$ to measure rectal temperature by inserting the probe.

\section{Statistical analysis}

Data on feed intake and rectal temperature were analyzed by repeated-measures two-way analysis of variance (ANOVA). Plasma metabolites were statistically analyzed by one-way ANOVA and regression equations. When significant differences were found, the comparison of means was performed using Tukey's test as a post hoc test. Differences were considered significant at $\mathrm{p}<0.05$. Values are presented as means \pm SEM. Statistical analysis 
was carried out using the commercially available package StatView (Version 5, SAS Institute, Cary, USA). Data were checked by the Thompson rejection test to eliminate outliers ( $\mathrm{p}<0.05$ ), and the remaining data were used for the analysis among groups.

\section{RESULTS AND DISCUSSION}

The aim of the current study was to reveal whether the LCit amino acid influenced feed intake and have thermoregulatory functions in KUB chicks. Feed intake was not significantly affected by oral administration of several doses of L-Cit (data not shown). This result was consistent with the previous report by Erwan et al. (2016) who revealed that the inclusion of watermelon rind in ration during two weeks did not influence feed intake in broiler chicks. However, the aforementioned authors demonstrated that feed consumption increased when chicks fed for three weeks. The present findings also contrasted with previous findings in layers where L-Cit given for up to $9 \%$ caused a significant increase in feed intake in male layer chicks (Nguyen et al., 2019). These discrepancies in the feed intake in response to L-Cit may be due to variations in the experimental period, differences in doses, or species differences. Further experimentation would be needed to clarify the factors involved in this disparity.

As shown in diagram 1, rectal temperatures of KUB chicks did not change significantly by the oral administration of L-Cit ( $p>0.05)$. This result was not consistent with the previous report that indicated the oral administration of L-Cit decreased the body temperature in layer and broiler chicks (Erwan and Febriyanti, 2015; Chowdhury et al., 2017). The body temperature of KUB chicks ranged from 39.5 to $40.5{ }^{\circ} \mathrm{C}$, which was still in the normal range. The different effects observed in this study can be attributed to the difference in chicken type. It is well known that indigenous chickens are more adaptable to stress than commercial chickens. Duangjinda (2017) revealed that indigenous chickens from a tropical environment had lower heterophil-to-lymphocyte ratio and mortality rate than those of commercial broilers under heat stress conditions. Similarly, Aengwanich (2007) revealed that Thai indigenous chickens and Thai crossbreed chickens can tolerate higher temperatures than broiler chickens.

Table 2 shows the effect of oral administration of different doses of L-Cit on certain biochemical parameters of plasma, indicating no significant changes were observed ( $p>0.05)$. The effect of oral administration of L-
Cit on total cholesterol, triacylglycerol, and glucose in the plasma of indigenous chicks is unclear. Watermelon rind contains a natural source of citrulline (Rimando and Perkins-Veazie, 2005). A previous study found that oral administration of red watermelon rind juice dosedependently increased glucose and triacylglycerol in broiler chickens (Erwan et al., 2016). In contrast, Chowdhury et al. (2017) revealed that oral administration of L-Cit decreased glucose in layer male chicks. It is thought the differences in results may be due to different strains of chicken used.

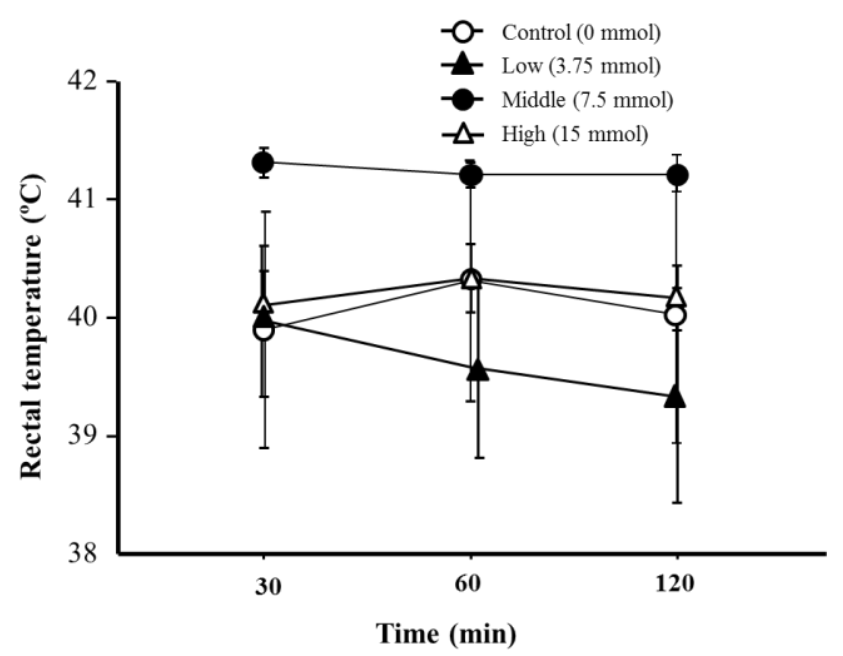

Diagram 1. The effect of different doses of L-citrulline on body temperature of KUB chicks over two hours after oral administration.

Table 2. Effects of oral administration of different doses of L-citrulline on plasma metabolites in KUB chicks

\begin{tabular}{lcccc}
\hline \multirow{2}{*}{ Parameters } & \multicolumn{4}{c}{ L-citrulline (mmol) } \\
\cline { 2 - 5 } & $237 \pm 20$ & $229 \pm 14$ & $261 \pm 8$ & $226 \pm 18$ \\
\hline Glucose $(\mathrm{mg} / \mathrm{d} l)$ & $161 \pm 12$ & $187 \pm 27$ & $177 \pm 25$ & $179 \pm 21$ \\
$\begin{array}{l}\text { Total cholesterol } \\
(\mathrm{mg} / \mathrm{d} l)\end{array}$ & & & \\
Triacylglycerol $(\mathrm{mg} / \mathrm{d} l)$ & $80 \pm 20$ & $49 \pm 9$ & $91 \pm 25$ & $51 \pm 8$ \\
\hline Values are expressed as mean \pm SEM. & & &
\end{tabular}

Heat stress affects plasma metabolites in poultry (Xie et al., 2015). An increase in plasma cholesterol indicates that chick has undergone heat stress (Olanrewaju et al., 2010). According to Altan et al. (2000), cholesterol in the body can come from de novo biosynthesis. De novo cholesterol biosynthesis is largely influenced by the broiler stress level (Setyadi et al., 2013). Blood cholesterol levels in this study ranged from 161 to $187 \mathrm{mg} / \mathrm{dl}$, whereas Basmacioglu and Ergul (2005) reported that serum cholesterol contents of laying hens renged from 121 to 142 $\mathrm{mg} / \mathrm{dl}$ ) 
The results obtained in the present study indicated that triacylglycerol ranged from $49-91 \mathrm{mg} / \mathrm{dl}$. When chickens are in a state of heat stress, plasma triacylglycerol levels drop (Sun et al., 2015). Environmental stress increases adrenocorticotropic hormone which stimulates the adrenal cortex to increase glucocorticoid secretion (von Borell and Ladewig, 1989). Blood glucose has a relationship with heat ambient temperature in poultry (Olanrewaju et al., 2010). Chowdhury et al. (2017) suggested that lower plasma glucose after oral administration of L-Cit may decrease the substrate for heat production and result in lower body temperature in chicks. Glucose in the blood serves as a buffer molecule for osmotic pressure thus normal osmotic pressure can be maintained even in a state of dehydration and heat stress (Guay et al., 2007) to maintain blood pressure and cardiovascular rhythms (Tan et al., 2010). In this study glucose concentration in chickens' blood ranged from $226-261 \mathrm{mg} / \mathrm{dl}$. This range is included in the normal glucose levels, which indicates the chickens did not experience heat stress. Normal range glucose concentration in broiler blood is $230-370 \mathrm{mg} / \mathrm{dl}$ (Sulistyoningsih, 2004).

\section{CONCLUSION}

L-citrulline could not able to improve feed intake and affect on body temperature in KUB chickens. No significant changes in plasma glucose, total cholesterol and triacylglycerol were detected in the current study,indicating the oral administration of L-citrulline may not affect the metabolism of these components in KUB chicks.

\section{DECLARATIONS}

\section{Acknowledgment}

All authors are very grateful to the Dean of Faculty of Agriculture and Animal Science, State Islamic University of Sultan Syarif Kasim Riau, Indonesia for supporting.

\section{Authors' contribution}

Edi Erwan conducted the research, prepared data, performed the statistical analysis and wrote draft article. Vebera Maslami, Triani Adelina and Alaiddin Koto wrote the article. All authors checked and approved the final version of the manuscript.

\section{Competing interests} interests.

\section{REFERENCES}

Aengwanich W (2007). Comparative ability to tolerate heat between Thai indigenous chickens, Thai indigenous chickens crossbred and broilers by using heterophil/lymphocyte ratio. Pakistan Journal of Biological Sciences, 10: 1840-1844. DOI: https://doi.org/10.3923/pjbs.2007.1840.1844.

Altan O, Cabuk M and Bayraktar H (2000). Effect of heat stress on some blood parameters in broiler. Turkish Journal of Veterinary and Animal Sciences, 24: 145-148. Available at: https://www.researchgate.net/publication/279937711_Effects_of_ Heat_Stress_on_Some_Blood_Parameters_in_Broilers.

Basmacioglu $\mathrm{H}$ and Ergul M (2005). Research on the factor affecting cholesterol content and some other characteristics of eggs in laying hens. Turkish Journal of Veterinary and Animal Sciences, 29:157-164. Available https://dergipark.org.tr/en/download/article-file/132841.

Chowdhury VS, Han G, Bahry MA, Tran PV, Do PH, Yang H and Furuse M (2017). L-Citrulline acts as potential hypothermic agent to afford thermotolerance in chicks. Journal Thermal Biology, 69:163-170. DOI: https://doi.org/10.1016/j.jtherbio.2017.07.007.

Chowdhury VS, Shigemura A, Erwan E, Ito K, Bahry MA, Tran V and Furuse M (2015). Oral administration of L-citrulline, but not Larginine or L-ornithine, acts as a hypothermic agent in chicks. The Journal of Poultry Science, 52: 331-335. DOI: https://doi.org/10.2141/jpsa.0150014.

Daghir NJ, Farran MT, Barbour GW and Beck MM (2003). Nutritive value of high-oil corn grown under semi-arid conditions and its impact on broiler performance and carcass composition. Poultry Science, 82:267-271. DOI: https://doi.org/10.1093/ps/82.2.267.

Duangjinda M, Tunim SI Duangdaen C and Boonkum WI (2017). Hsp70 genotypes and heat tolerance of commercial and native chickens reared in hot and humid condition. Brazilian Journal of Poultry Science, 19:7-17. DOI: http://dx.doi.org/10.1590/1806-90612016-0245.

Erwan E and Febriyanti R (2015). Studi potensi asam amino L-citrulline sebagai agen anti heat stress melalui oral administration pada ayam broiler. Laporan Penelitian. LPPM Uin Suska Riau.

Erwan E, Chowdhury VS, Ito K and Furuse M (2013a). Lauroyl-Laspartate decreased food intake and body temperature in neonatal chicks. Pharmacology Biochemistry and Behavior, 13:7-11. DOI: https://doi.org/10.1016/j.pbb.2013.10.010.

Erwan E, Chowdhury VS, Nagasawa M, Goda R, Otsuka T, Yasuo S and Furuse M (2014). Oral administration of D-aspartate, but not Laspartate, depresses rectal temperature and alters plasma metabolites in chicks. Life Sciences, 109: 65-71. DOI: https://doi.org/10.1016/j.lfs.2014.05.015.

Erwan E, Fitra D, Irawati E and Febriyanti R (2016). Studi potensi kulit buah semangka sebagai sebagai agen anti heat stress pada ayam pedaging/broiler. Laporan penelitian, LP2M Uin Suska Riau

Erwan E, Tomonaga S, Ohmori T, Mutaguchi Y, Ohshima T, Nagasawa M and Furuse M (2013b). Oral administration of D-aspartate, but not of L-aspartate, reduces food intake in chicks. The Journal of Poultry Science, 50: 164-171. DOI: https://doi.org/10.2141/jpsa.0120116.

Erwan E, Tomonaga S, Yoshida J, NagasawaM, Ogino Y, Denbow DM and Furuse M (2012) Central administration of L- and Daspartate attenuates stress behaviors by social isolation and CRF in neonatal chicks. Amino Acids, 43:1969-1976. DOI: https://doi.org/10.1007/s00726-012-1272-4.

Erwan E, Zulfikar, Saleh E, Kuntoro B, Chowdhury VS and Furuse M (2017). Orally administered D-aspartate depresses rectal temperature and alters plasma triacylglycerol and glucose 
concentrations in broiler chick.

The Journal of Poultry Science, 54:205-211. DOI: https://doi.org/10.2141/jpsa.0160010.

Franco-Jimenez DJ and Beck MM (2007). Physiological changes to transient exposure to heat stress observed in laying hens. Poultry Science, 86:538-44. DOI: https://doi.org/10.1093/ps/86.3.538.

Goo D, Kim JH, Park GH, Delos Reyes JB and Kil DY (2019). Effect of heat stress and stocking density on growth performance, breast meat quality, and intestinal barrier function in broiler chickens. Animals, 9:1-10. DOI: https://doi.org/10.3390/ani9030107.

Hamasu K, Shigemi K, Tsuneyoshi Y, Yamane H, Sato H, Denbow DM and Furuse M (2010). Intracerebroventricular injection of Lproline and D-proline induces sedative and hypnotic effects by different mechanisms under an acute stressful condition in chicks. Amino Acids, 38:57-64. DOI: https://doi.org/10.1007/s00726008-0204-9.

Hidayah R, Ambarsari I and Subiharta S (2019). Study of physical, nutritional and sensory properties KUB chicken meat in Central Java. Jurnal Peternakan Indonesia, 21 (2): 93-101. DOI: https://doi.org/10.25077/jpi.21.2.93-101.2019.

Lin H, Mertens K, Kemps B, Govaerts T, De Ketelaere B, De Baerdemaeker J, Decuypere E and Buyse J (2004). New approach of testing the effect of heat stress on egg quality: mechanical and material properties of eggshell and membrane. British Poultry Science, $\quad 45: 476-82 . \quad$ DOI: https://doi.org/10.1080/00071660400001173.

Mendes AA, Watkins SE, England JA, Saleh EA, Waldroup AL and Waldroup PW (1997). Influence of dietary lysine levels and arginine: lysine ratios on performance of broilers exposed to heat or cold stress during the period of three to six weeks of age. Poultry Science, 76: 472-481. DOI: https://doi.org/10.1093/ps/76.3.472.

Nguyen LTN, Han G, Yang H, Ikeda H, Eltahan HM, Chowdhury VS and Furuse $M$ (2019). Dried watermelon rind mash diet increases plasma L-citrulline level in chicks. The Journal of Poultry Science, 56: 65-70. DOI: https://doi.org/10.2141/jpsa.0180018.

Olanrewaju HA, Purswell JL, Collier SD and Branton SL (2010). Effect of ambient temperature and light intensity on physiological reactions of heavy broiler chickens. Poultry Science, 89: 26682677. DOI: https://doi.org/10.3382/ps.2010-00806.

Padhi MK (2016). Importance of indigenous breeds of chicken for rural economy and their improvements for higher production performance, Scientifica, 2016, 1-9. DOI: http://dx.doi.org/10.1155/2016/2604685.

Purbarani SA, Wahyuni HI and Suthama N (2019). Dahlia inulin and Lactobacillus $s p$. in step down protein diet on villi development and growth of KUB chickens. Tropical Animal Science Journal, 42:19-24. DOI: https://doi.org/10.5398/tasj.2019.42.1.19

Renaudeau D, Collin A, Yahav S, de Basilio V, Gourdine JL and Collier RJ (2012). Adaptation to hot climate and strategies to alleviate heat stress in livestock production. Animal, 6:707-728. DOI: https://doi.org/10.1017/S1751731111002448.
Rimando AM and Perkins-Veazie PM (2005). Determination of citrulline in watermelon rind. Journal of Chromatography A, 1078:196-200. https://doi.org/10.1016/j.chroma.2005.05.009.

Sartika T (2016). Panen Ayam Kampung 70 hari. Penebar Swadaya, Jakarta.

Setyadi F, Ismadi VDYB dan Mangisah I (2013). Kadar kolesterol, HDL dan LDL darah akibat kombinasi lama pencahayaan dan pemberian porsi pakan berbeda pada ayam broiler. Animal Agriculture Journal, 2: 68-76. Available at: https://ejournal3.undip.ac.id/index.php/aaj/article/view/2045/204 3 .

Sterling KG, Bell DD, Pesti GM and Aggrey SE (2003). Relationships among strain, performance, and environmental, temperature in commercial laying hens. Journal of Applied Poultry Research, 2:85-91. DOI: https://doi.org/10.1093/japr/12.1.85.

Sulistyoningsih M (2004). Respon Fisiologis dan Tingkah Laku Ayam Brolier Starter Akibat Cekaman Tempratur dan Awal Pemberian Pakan yang Berbeda. Tesis. Magister Ilmu Ternak Program Pasca Sarjana Universitas Diponegoro. Semarang.

Sun X, Zhang H, Sheikhahmadi A, Wang Y, Jiao H, Lin H and Song Z (2015). Effects of heat stress on the gene expression of nutrient transporters in the jejunum of broiler chickens (Gallus gallus domesticus). International Journal Biometeorology, 59:127-135. DOI: http://dx.doi.org/10.1007/s00484-015-0996-8.

Tan GY, Yang L, Fu YQ, Feng JH and Zhang MH (2010). Effects of different acute high ambient temperatures on function of hepatic mitochondrial respiration, antioxidative enzymes and oxidative injury in broiler chickens. Poultry Science, 89: 115-122. DOI: https://doi.org/10.3382/ps.2009-00318.

Teeter RG and Belay T (1996). Broiler management during acute heat stress. Animal Feed Science and Technology, 58:127-142. DOI: https://doi.org/10.1016/0377-8401(95)00879-9.

Von Borell E and Ladewig J (1989). Altered adrenocortical response to acute stressors or ACTH (1-24) in intensively housed pigs. Domestics Animal. Endocrinology, 6:299-309. DOI: https://doi.org/10.1016/0739-7240(89)90024-6.

Xie J, Tang L, Lu L, Zhang L, Xi L, Liu HC, Odle J and Luo X (2014). Differential expression of heat shock transcription factors and heat shock proteins after acute and chronic heat stress in laying chickens (Gallus gallus). PLoS One, 9: 1-9. DOI: https://doi.org/10.1371/journal.pone.0102204.

Yahav S (2000). Domestic fowl-strategies to confront environmental conditions. Avian and Poultry Biology Reviews, 11:81-95.

Yamane H, Asechi M, Tsuneyoshi Y, Kurauchi I, Denbow DM and Furuse M (2009). Intracerebroventricular injection of L-aspartic acid and L-asparagine induces sedative effects under an acute stressful condition in neonatal chicks. Animal Science Journal, 80:286-290. DOI: $\quad$ https://doi.org/10.1111/j.17400929.2009.00625.x. 